\title{
Perencanaan lanskap bantaran Tukad Unda sebagai waterfront park (studi kasus: Dam Lebah Kabupaten Klungkung)
}

\author{
Ida Ayu Patni Dewi' ${ }^{1}$, Lury Sevita Yusiana ${ }^{1}$, Ni Nyoman Ari Mayadewi2*
}

1. Prodi Arsitektur Pertamanan, Fakultas Pertanian, Universitas Udayana, Indonesia 80232

2. Prodi Agroekoteknologi, Fakultas Pertanian, Universitas Udayana, Indonesia 80232

*Email: lury.yusiana@unud.ac.id

\begin{abstract}
Landscape planning of the Unda riverbanks as waterfront park (case study: Lebah Dam, Klungkung). Tukad Unda is a river which has continuous flows and quite high rainfall, therefore, it is very potential to be developed, however it still has large destroying effects for the community if it is not well-managed. The planning of Tukad Unda's Landscape as a waterfront park in Klungkung Regency is chosen as a topic in this research to identify and analyse the activities and facilities which is suitable with the development concept and the planning of Tukad Unda's Landscape as a waterfront park that serves as a river conservation as well as recreational area for the nearby society. Research method used in this study is survey method with observational technique and literature survey. Stages of this study was a foundation in the planning-making includes the inventory, analysis and synthesis, and concept-making. The result showed that waterfront park in Unda River can give benefit to the surrounding people for green open space and social interaction space. The result of this study is expected to provide ideas to the society on how essential the rivers' roles to the advancement of the environmental quality.
\end{abstract}

Key words: landscape planning, waterfront park, Tukad Unda

\section{Pendahuluan}

Tukad Unda merupakan sungai yang terbentuk dari bahan kwatair vulkanik, dan memiliki daerah pengaliran dan pengendapan material lahar hasil letusan gunung yang mencakup wilayah Kabupaten Karangasem di bagian hulunya, dan Kabupaten Klungkung di bagian hilirnya. Karakteristik Tukad Unda yaitu memiliki lebar dasar sungai berkisar antara $10 \mathrm{~m}$ sampai $67 \mathrm{~m}$, tinggi air normal antara $50 \mathrm{~cm}$ sampai $200 \mathrm{~cm}$, tinggi air banjir dari dasar sungai kurang lebih $600 \mathrm{~cm}$ (Balai Wilayah Sungai Bali-Penida, 2017).

Debit banjir yang terjadi hampir setiap tahun dapat mengakibatkan bahaya kestabilan tebing-tebing sungai. Perencanaan lanskap Tukad Unda sebagai waterfront park dapat memberikan ruang untuk berbagai aktivitas yang dibutuhkan masyarakat sekitar dan dapat meningkatkan kualitas lingkungan kota. Berdasarkan uraian tersebut Tukad Unda membutuhkan suatu sistem pemanfaatan yang mampu mengkonservasi dan mampu memberi manfaat sosial bagi masyarakat sekitar Tukad Unda.

Tujuan penelitian ini yaitu membuat perencanaan lanskap Tukad Unda sebagai waterfront park yang berfungsi sebagai konservasi sungai dan rekreasi bagi masyarakat sekitar. Perencanaan lanskap Tukad Unda sebagai waterfront park dapat memberikan ruang untuk berbagai aktivitas yang dibutuhkan masyarakat sekitar. Waterfront park juga dapat meningkatkan estetika lingkungan, menghasilkan lanskap yang panoramik dan rekreatif pada daerah sekitar sungai dan juga untuk peningkatan kualitas wajah kota secara keseluruhan.

\section{Metode Penelitian}

Penelitian ini dilakukan pada Bulan Mei 2018 yang berlokasi di Tukad Unda Kelurahan Semarapura Kangin, di area dam Tukad Unda Desa Lebah bagian muara yang ada di wilayah Kabupaten Klungkung. Wilayah ini terletak di antara $115^{\circ} 27^{\prime}-37^{\prime \prime} 8^{\circ} 49^{\prime} 00^{\prime \prime}$ LS dengan luas $315 \mathrm{Km}^{2}$ terlihat pada Gambar 1. 


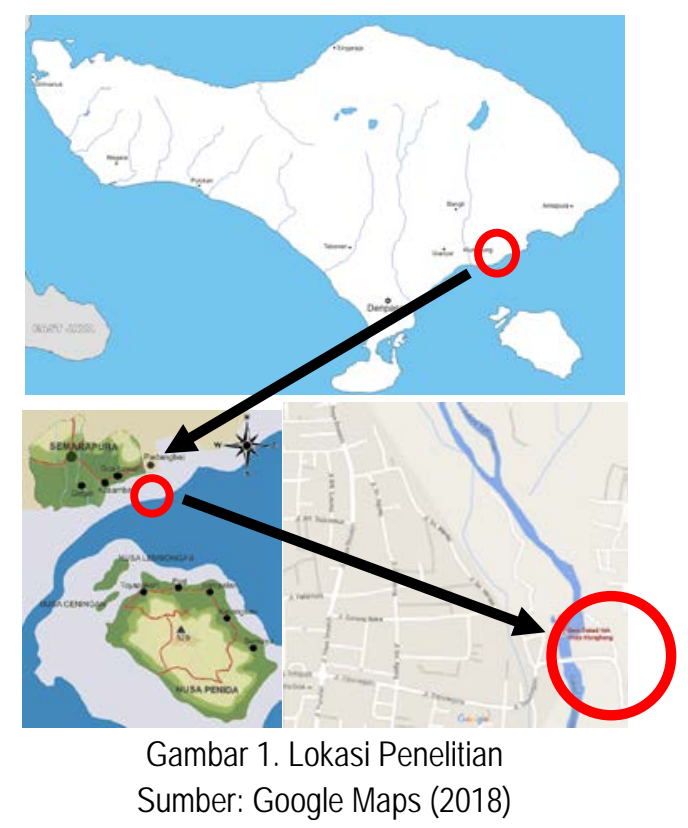

Alat yang digunakan untuk penelitian ini meliputi alat tulis, kamera digital, perekam suara, meteran, dan laptop dengan perangkat lunak Google Earth, Autocad 2016, Google Skecthup 2015, dan Adobe Photoshop CS7. Bahan yang digunakan dalam penelitian ini yaitu: peta dasar, dan peta penggunaan lahan Tukad Unda Kabupaten

Klungkung Tahun 2017.

Metode yang digunakan dalam penelitian adalah metode survei dengan pengumpulan data melalui observasi dan studi pustaka. Perencanaan lanskap dibuat menurut tahapan Gold (1980). Tahapan-tahapan dalam perencanaan tersebut adalah: persiapan, inventarisasi, analisis, sintesis perencanaan dan perancangan. Penelitian ini hanya dilakukan sampai tahap perencanaan dengan menganalisis kondisi biofisik pada tapak dan potensi pemanfaatan.

Penelitian dilakukan di bantaran Tukad Unda Dam Lebah, Kelurahan Semarapura Kangin, Klungkung dengan melakukan perencanaan bantaran sungai sepanjang $500 \mathrm{~m}$. Batas lokasi bagian selatan adalah jembatan yang menghubungkan Kecamatan Klungkung dan Kecamatan Dawan memanjang ke arah utara sepanjang $500 \mathrm{~m}$. Panjang $500 \mathrm{~m}$ digunakan karena yang direncanakan pada wilayah Kelurahan Semarapura Kangin dan merupakan area yang digunakan masyarakat untuk aktivitas. Produk penelitian yang dihasilkan berupa gambar rencana tapak (site plan) Tukad Unda sebagai waterfront park yang menekankan pada fungsi konservasi dan rekreasi.

\section{Hasil dan Pembahasan \\ 3.1 Gambaran Umum}

Lokasi dam Tukad Unda terletak di Kelurahan Semarapura Kangin, Kecamatan Klungkung, Kabupaten Klungkung. Batas-batas tapak lokasi penelitian adalah kawasan Tukad Unda pada bagian utara, jembatan pada sebelah selatan. Luas keseluruhan lokasi penelitian yaitu pada bantaran bagian barat memiliki luas sekitar $31.184 \mathrm{~m} 2$, sedangkan luas bantaran pada bagian timur memiliki luas sekitar $9.501 \mathrm{~m} 2$. Keseluruhan tapak yang direncanakan memiliki luas $40.685 \mathrm{~m}$. Batas-batas tapak lokasi penelitian dapat dilihat pada Gambar 2. 


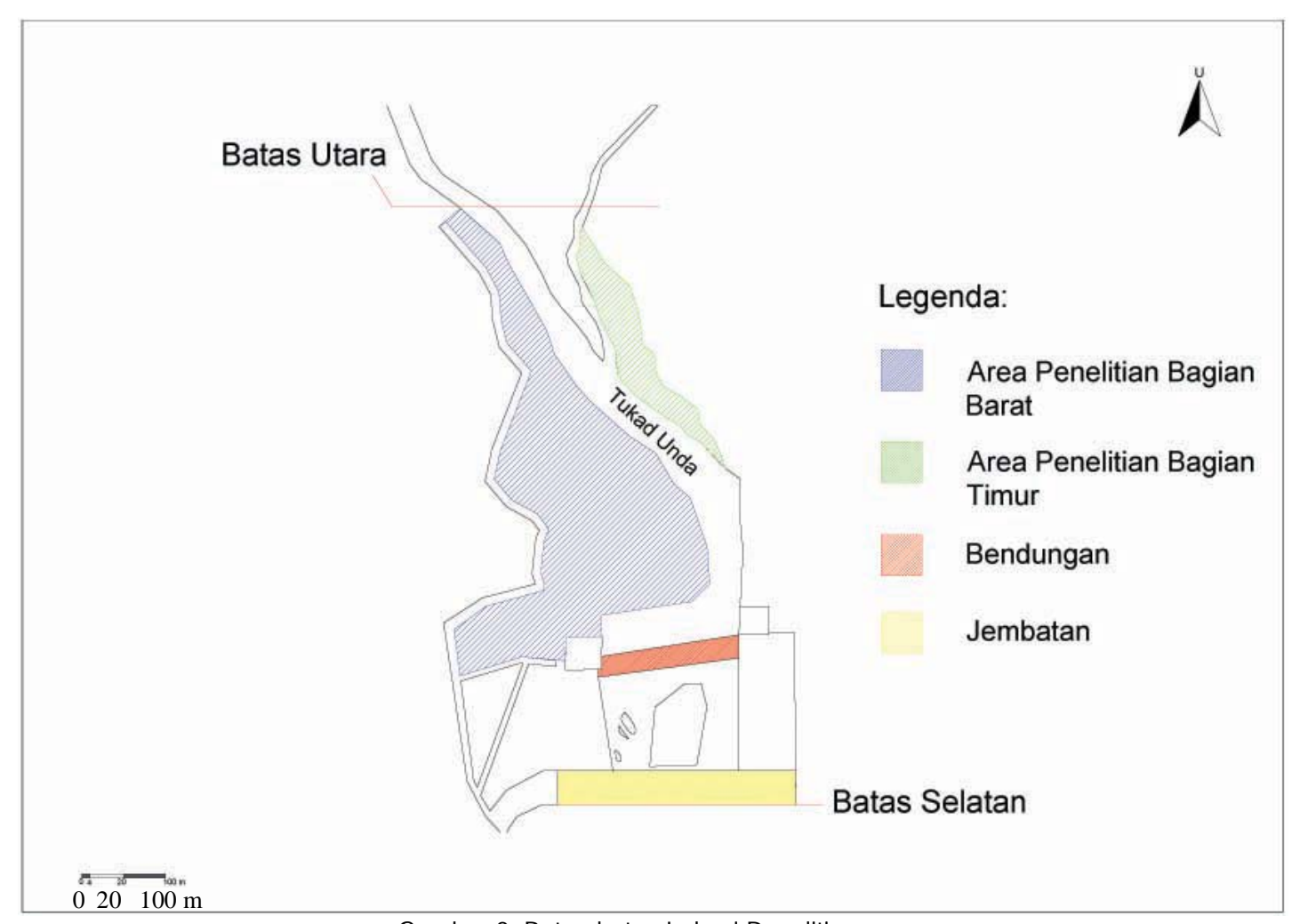

Gambar 2. Batas-batas Lokasi Penelitian.

Sumber: Pengolahan Data, 2017.

\subsection{Analisis dan Sintesis}

Tahap analisis dan sintesis merupakan tahapan dalam mengolah data hasil yang didapatkan pada tahap inventarisasi yang selanjutnya diolah sehingga mengetahui potensi dan masalah yang ada.

Lokasi pada tapak tidak memiliki fasilitas yang menghubungkan antara bantaran bagian timur dan bantaran bagian barat. Sirkulasi yang terdapat pada tapak antara lain yaitu sirkulasi manusia dan kendaraan. Kondisi jalur manusia dan kendaraan belum memadai karena hanya menggunakan satu jalur saja.

Terkait dengan pemanfaatan potensi wilayah bantaran sungai, bantaran Tukad Unda memiliki potensi yang dapat dikembangkan menjadi sebuah ruang yang bermanfaat bagi publik, dengan mempertimbangkan berbagai potensi dalam bentuk ruang publik yang bersifat rekreatif. Bantaran Tukad Unda di lokasi penelitian memiliki permasalahan penataan, kebersihan dan fasilitas. Permasalahan yang dihadapi antara lain akses menuju bantaran kurang memadai, kurang tertatanya elemen softscape serta belum tersedianya fasilitas seperti bangku, jalan setapak dan parkir kendaraan yang dapat mendukung aktivitas masyarakat. Berdasarkan inventarisasi kondisi visual pada tapak terdapat potensi dari good view yang dapat dimanfaatkan sebagai daya tarik utama dan perlu diberi beberapa elemen pendukung agar potensi tersebut memiliki manfaat yang lebih optimal.

Ancaman yang ada di bantaran Tukad Unda ini yaitu tapak dekat dengan area pusat kota sehingga dekat dengan polusi kendaraan, penduduk cukup padat, dan debit air yang tinggi pada saat periode curah hujan meningkat. Curah hujan rata-rata sebesar 1357 mm (Badan Pusat Statistik Kabupaten Klungkung, 2017). Curah hujan pada kawasan ini tinggi pada Bulan Desember-April sehingga menyebabkan ketinggian air meningkat $600 \mathrm{~cm}$ dan lokasi tapak terletak di daerah rawan longsor sehingga diperlukan analisis vegetasi pada tapak ini.

Dalam menganalisa vegetasi pada tapak diperlukan pengetahuan terhadap fungsi-fungsi vegetasi tersebut. Menurut Hakim dan Utomo (2002) tanaman tidak hanya mempunyai nilai estetis saja, tetapi juga berfungsi untuk meningkatkan kualitas lingkungan, sehingga tanaman memiliki beberapa kategori fungsi 
seperti kontrol pandangan, pembatas fisik, pengendali iklim, pencegah erosi, habitat satwa dan nilai estetis. Analisis fungsi vegetasi pada tapak dapat dilihat pada Tabel 1.

Tabel 1. Analisis dan Sintesis Fungsi Vegetasi

\begin{tabular}{rrrr}
\hline No & Fungsi Vegetasi & Analisis & Sintesis \\
\hline 1. & Pembatas Fisik & $\begin{array}{l}\text { Sudah ada vegetasi eksisting } \\
\text { yang memiliki fungsi tersebut } \\
\text { namun kurang tertata. }\end{array}$ & Menata vegetasi yaitu vegetasi \\
& & pengarah seperti bambu.
\end{tabular}

2. Kontrol Iklim Mikro

Tanaman yang ada pada tapak telah memenuhi kriteria sebagai pengendali iklim dalam mengendalikan radiasi sinar matahari dan suhu.

3. Pencegah Erosi

4. $\quad$ Nilai Estetis
Tanaman yang ada pada tapak telah memenuhi kriteria sebagai pencegah erosi.

Bentukan tanaman belum memenuhi kriteria.
Mempertahankan tanaman
kenanga, lamtoro.

Mempertahankan tanaman
kenanga, lamtoro.

Mempertahankan vegetasi yang diperlukan yaitu vegetasi penahan air yang jatuh kepermukaan tanah dan daya serap air yang tinggi serta memiliki akar yang kuat seperti bambu, kayu manis, lamtoro, mangga, rambutan, kenanga.

Memilih jenis tanaman yang mendukung fungsi tapak untuk menambah kualitas lingkungan.

\section{Sumber: Pengolahan Data, 2018.}

Lokasi tapak terletak di kawasan yang memiliki penduduk yang cukup padat dan masing-masing rumah penduduk di kawasan ini tidak memiliki pekarangan rumah, sehingga penduduk membutuhkan ruang terbuka publik untuk bersosial dan berekreasi. Upaya pemanfaatan potensi wilayah bantaran sungai menjadi sebuah ruang yang bermanfaat bagi publik diwujudkan sebagai suatu bentuk ruang terbuka yang direncanakan dengan potensi fisik dan non fisik yang ada pada wilayah bantaran Tukad Unda. Dengan adanya waterfront park di kawasan Tukad Unda selain menjadi ruang terbuka hijau kota bagi masyarakat, juga dapat menjadi ruang interaksi sosial. Mulai dari anak-anak hingga dewasa dapat memanfaatkan waterfront park sebagai tempat berekreasi.

Keberadaan waterfront park yang dapat diakses publik akan meningkatkan pemanfaatan kawasan dan diharapkan dapat menguatkan nilai optimalisasi fungsi utama wilayah bantaran sungai. Adanya penambahan fungsi ruang publik merupakan sebuah usaha mendekatkan manusia dengan lingkungannya dengan melakukan aktivitas relaksasi, rekreasi dan olahraga ringan pada fasilitas yang disediakan. Analisis dan sintesis fungsi sosial terlihat pada Tabel 2.

Tabel 2. Analisis dan Sintesis Fungsi Sosial

\begin{tabular}{cll}
\hline Fungsi Sosial & \multicolumn{1}{c}{ Analisis } & \multicolumn{1}{c}{ Sintesis } \\
\hline Ruang Terbuka Publik & $\begin{array}{l}\text { Penduduk yang cukup padat, } \\
\text { kebutuhan penduduk } \\
\text { terhadap ruang publik tinggi. }\end{array}$ & $\begin{array}{l}\text { Pemanfaatan potensi wilayah bantaran } \\
\text { sungai menjadi sebuah ruang yang } \\
\text { bermanfaat bagi publik diwujudkan sebagai } \\
\end{array}$ \\
& $\begin{array}{l}\text { suatu bentuk ruang terbuka publik pada } \\
\text { wilayah bantaran Tukad Unda. }\end{array}$ \\
\hline
\end{tabular}




\begin{tabular}{cll}
\hline Fungsi Sosial & \multicolumn{1}{c}{ Analisis } & \multicolumn{1}{c}{ Sintesis } \\
\hline \multirow{3}{*}{ Ruang Terbuka Hijau } & $\begin{array}{l}\text { Masyarakat sekitar kawasan } \\
\text { Tukad Unda tidak memiliki } \\
\text { ruang terbuka hijau. }\end{array}$ & $\begin{array}{l}\text { Mengkonservasi sumberdaya alam, } \\
\text { pengembangan lanskap kota dan mecegah } \\
\text { terjadinya bencana. }\end{array}$ \\
\hline
\end{tabular}

Sumber: Pengolahan Data, 2018.

\subsection{Konsep Dasar}

Konsep waterfront park dapat menjadi solusi mengelola wilayah rawan banjir yaitu bantaran sungai yang berfungsi sebagai konservasi dan rekreasi bagi masyarakat sekitar. Intensitas curah hujan yang tinggi mengakibatkan ketinggian air meningkat, penerapan konsep ini memiliki banyak manfaat selain sebagai upaya pencegahan dari dampak banjir itu sendiri, dapat juga memberi nilai estetika.

\subsection{Konsep Pengembangan}

Konsep pengembangan dibuat berdasarkan hasil analisis kesesuaian potensi biofisik dan sosial pada kawasan. Berdasarkan data yang didapatkan dan diolah pada tahap analisis dan sintesis, maka konsep yang sesuai dengan data yang diperoleh yaitu waterfront park sebagai konsep pengembangan daerah tepian air yang memiliki fungsi untuk meningkatkan resapan air, mengurangi pencemaran udara dan juga memiliki fungsi sebagai elemen dan ruang rekreasi alam, wisata dan kebutuhan upacara adat masyarakat Hindu.

\subsection{Konsep Ruang}

Konsep ruang yang direncanakan disesuaikan dengan kondisi tapak di Tukad Unda yaitu ruang yang mewadahi interaksi sosial budaya masyarakat dan sebagai ruang rekreasi alam. Aktivitas sosial budaya masyarakat kawasan Tukad Unda berupa kegiatan dalam berinteraksi sosial dan rekreasi alam.

\subsection{Tata Ruang}

Tata ruang merupakan penataan zonasi pada tapak. Zona yang dapat dikembangkan yaitu zona edukasi, zona rekreasi, dan zona konservasi. Zona edukasi yang dimaksud adalah ruang yang memiliki fungsi untuk berakivitas mengenal lingkungan. Zona rekreasi yang dimaksud adalah ruang yang memiliki fungsi untuk beraktivitas seperti bersantai dan menikmati alam sekitar. Zona Konservasi yang dimaksud adalah ruang yang memiliki tingkat kesesuaian sumber daya terhadap aktivitas rendah. Sehingga aktivitas pengunjung dibatasi di ruang ini, untuk menghindari terjadinya kerusakan pada sumber daya alam. Konsep tata ruang terlihat pada Gambar 3.

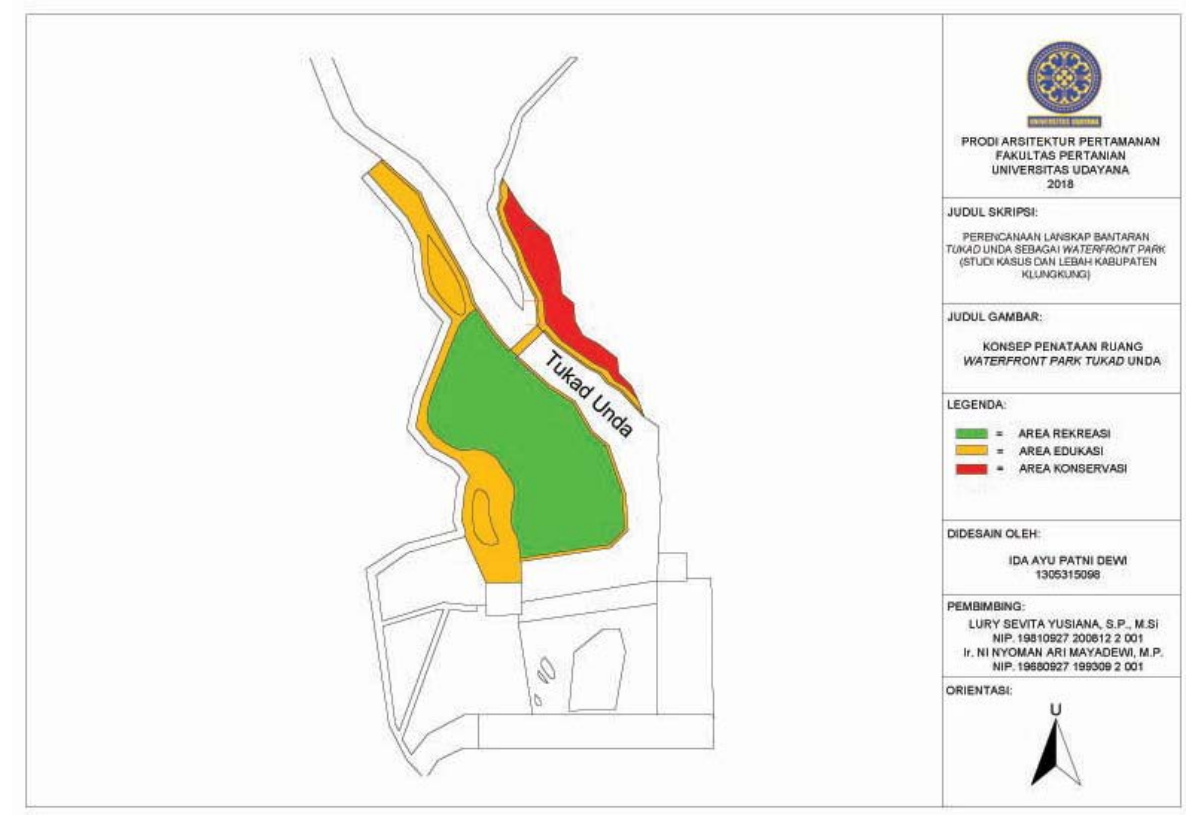

Gambar 3. Konsep Penataan Ruang Waterfront Park Tukad Unda 


\subsection{Konsep Sirkulasi}

Konsep sirkulasi dibuat berdasarkan hubungan antar ruang yang dimanfaatkan sebagai penghubung antara ruang yang dialokasikan dalam setiap zona yang ada dengan menambahkan fasilitas jembatan untuk mengakses tapak dari kondisi yang ada. Akses jalan tanah dan jalan perkerasan yang menghubungkan masing-masing obyek dalam setiap ruang merupakan jalur sirkulasi pendukung yang dapat dilalui dengan berjalan kaki.

\subsection{Tata Sirkulasi}

Tata sirkulasi dibuat berdasarkan hubungan antar ruang yang dimanfaatkan untuk memudahkan wisatawan berpindah dari satu tempat ke tempat lainnya. Pada tapak yang direncanakan terdapat dua jenis sirkulasi, yaitu sirkulasi kendaraan dan sirkulasi manusia. Sirkulasi kendaraan dimulai dari akses masuk ke dalam kawasan Tukad Unda kemudian ke area parkir, selanjutnya pintu keluar kawasann Tukad Unda. Sirkulasi manusia dibuat lurus memanjang mengikuti pola alami sungai serta dua arah. Konsep sirkulasi terlihat pada Gambar 4.

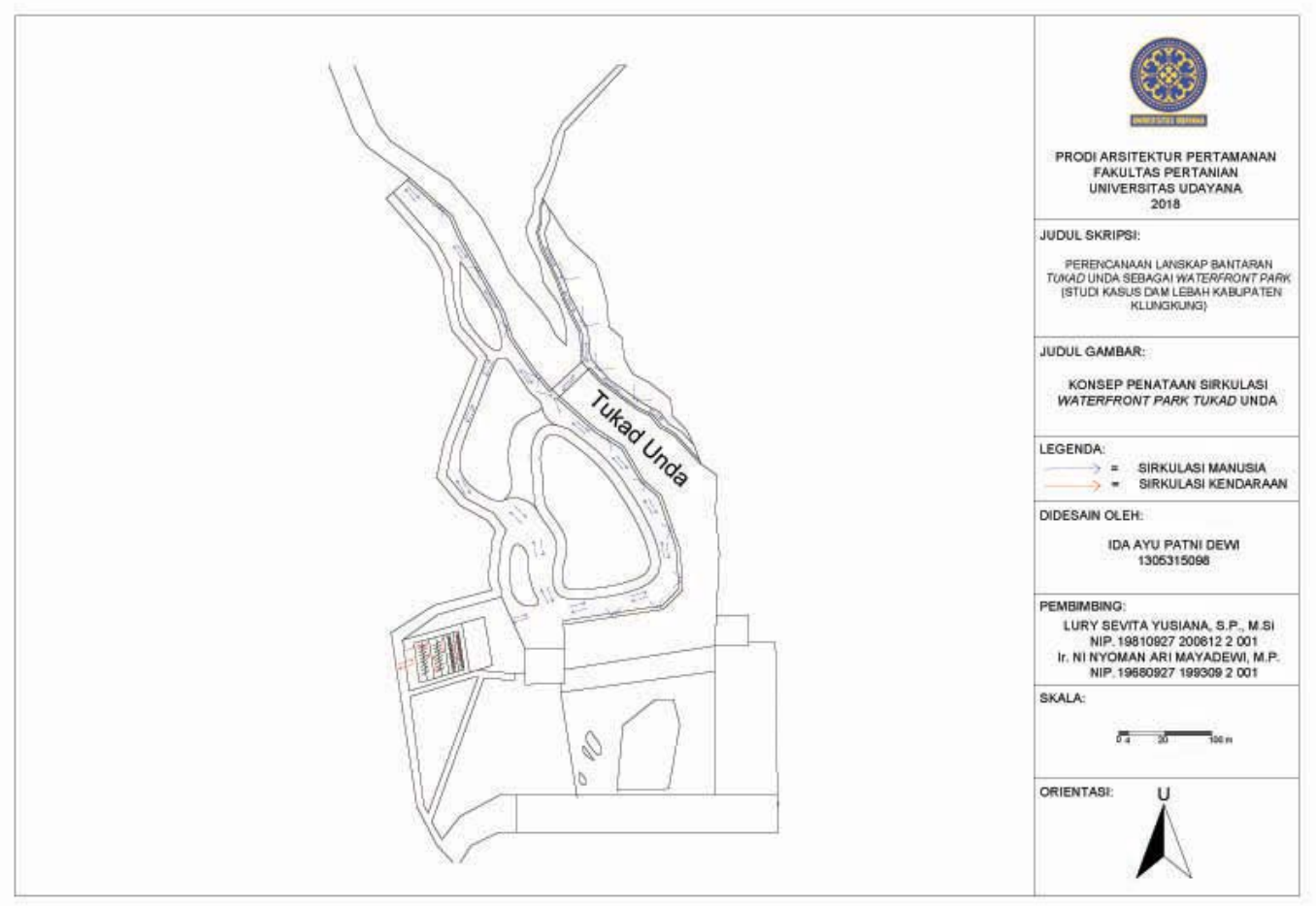

Gambar 4. Konsep Penanaman Vegetasi Waterfront Park Tukad Unda

\subsection{Konsep Tata Hijau}

Penerapan konsep berupa pemilihan jenis vegetasi yang disesuaikan dengan fungsinya diharapkan dapat menjadi pengontrol terhadap kondisi site pada tapak (bising, polusi, penghias, peneduh, pengarah dan pencegah erosi), selain itu diharapkan dapat meminimalisir terhadap penggunaan material maupun alat yang sifatnya tidak ramah lingkungan. Konsep pemilihan tanaman yaitu tanaman yang memiliki sistem perakaran yang kuat untuk dapat menahan air sehingga mencegah terjadinya erosi dan mendukung konservasi air dan tanah.

\subsection{Tata Hijau}

Tata hijau pada bantaran sungai diperkotaan memiliki 3 (tiga) fungsi dan tujuan utama yaitu untuk menjaga stabilitas dan keamanan tebing guna meminimumkan terjadinya erosi tanah, meningkatkan kenyamanan lingkungan kota, dan meningkatkan estetika alami di perkotaan. Bila 3 (tiga) fungsi utama dari keberadaan bantaran sungai ini telah diaplikasikan dengan baik maka fungsi dan tujuan pendukung lainnya 
akan dapat ditambahkan tanpa mengganggu fungsi utamanya. Fungsi pendukung ini antara lain menghalangi masuknya sampah dan limbah, meresapkan air, wadah rekreasi dan sumber pendapatan warga kota dan lainnya. Jadi jenis vegetasi pada tapak harus memiliki sistem perakaran yang dalam dan melebar yang dapat megikat tanah sehingga dapat mengurangi erosi tanah. Sistem perakaran ini juga dapat menyaring air kotor yang masuk ke dalam sungai. Sistem perakaran yang rapat seperti pohon bambu (Bambusa sp.) juga berperan dalam mencegah erosi tanah. Konsep penanaman vegetasi terlihat pada Gambar 5.

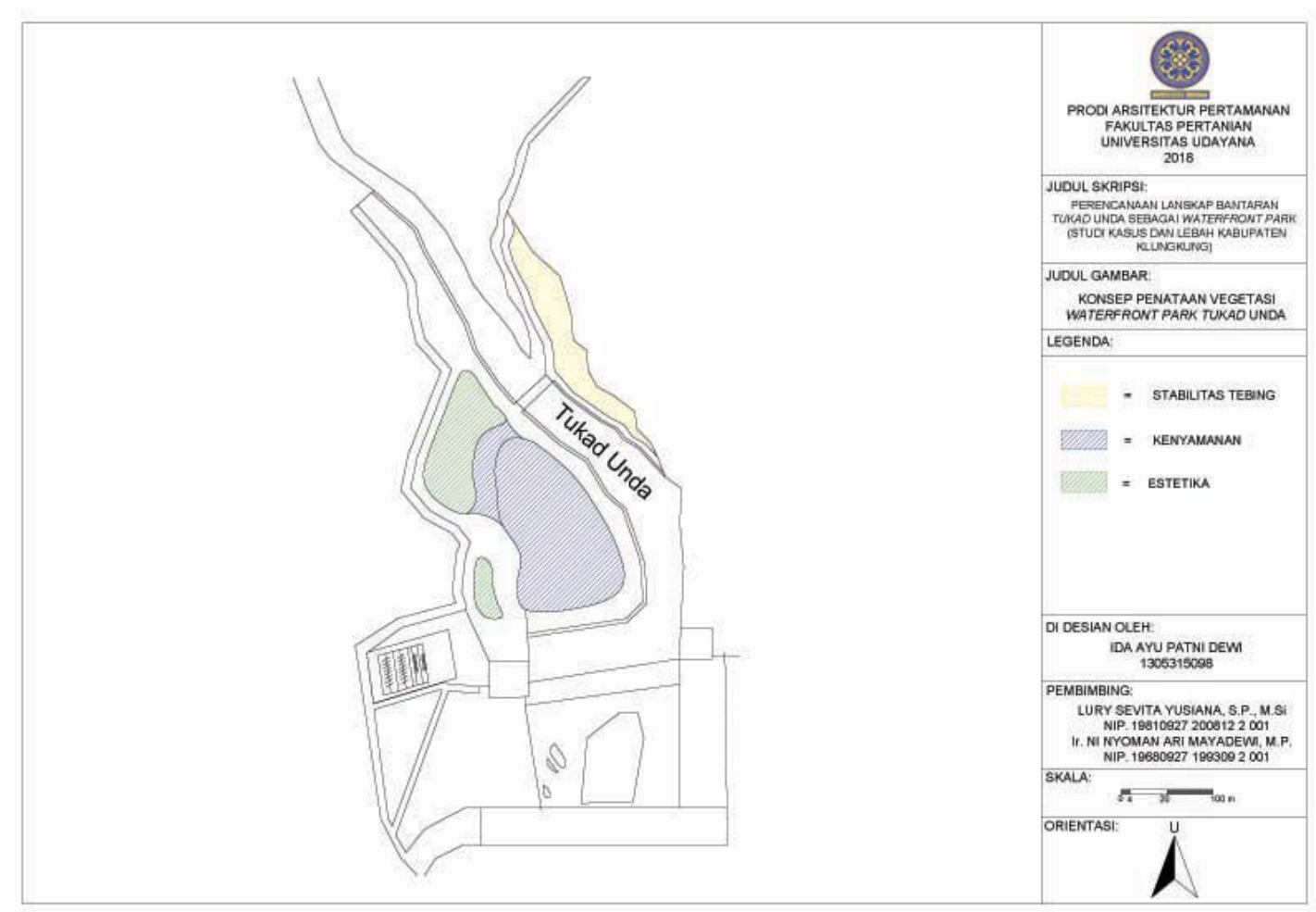

Gambar 5. Konsep Penanaman Vegetasi Waterfront Park Tukad Unda

\subsection{Hubungan Ruang}

Ruang menjadi wadah untuk melakukan aktivitas, di mana aktivitas yang akan dilakukan disesuaikan dengan fungsi yang akan dikembangkan pada ruang tersebut. Ruang, aktivitas dan fasilitas memiliki hubungan antara satu dengan lainnya dan menjadi satu kesatuan sehingga semua kegiatan yang dilakukan pengunjung dapat dilakukan dengan baik dan didukung dengan fasilitas sesuai dengan kebutuhan tapak.

Tabel 2. Hubungan antara Zona, Aktivitas dan Fasilitas

\begin{tabular}{lll}
\hline \multicolumn{1}{c}{ Zona } & \multicolumn{1}{c}{ Aktivitas } & \multicolumn{1}{c}{ Fasilitas } \\
\hline Rekreasi & $\begin{array}{l}\text { Bersantai, melihat }- \text { lihat, fotografi, } \\
\text { berkemah }\end{array}$ & $\begin{array}{l}\text { Tempat duduk, jalan setapak, area } \\
\text { berkemah }\end{array}$ \\
Edukasi & $\begin{array}{l}\text { Mengenal tanaman yang ada pada } \\
\text { bantaran Tukad Unda }\end{array}$ & $\begin{array}{l}\text { Jalan setapak, papan penjelasan } \\
\text { vegetasi sungai }\end{array}$ \\
Konservasi & $\begin{array}{l}\text { Tidak terdapat aktivitas di area } \\
\text { konservasi }\end{array}$ & $\begin{array}{l}\text { Tidak terdapat fasilitas di area } \\
\text { konservasi }\end{array}$ \\
\hline
\end{tabular}


Hubungan antara zona, aktivitas dan fasilitas yang dikembangkan pada zona rekreasi yaitu berfungsi sebagai ruang untuk bersantai, fotografi, berkemah atau melihat-lihat. Fasilitas yang disediakan yaitu tempat duduk dan jalan setapak. Zona edukasi berfungsi sebagai ruang untuk pengenalan tanaman dan fungsi tanaman yang ada pada bantaran Tukad Unda. Fasilitas yang disediakan yaitu jalan setapak. Zona konservasi merupakan ruang yang memiliki tingkat kesesuaian sumber daya terhadap aktivitas rendah. Aktivitas pengunjung dibatasi di ruang ini, untuk menghindari terjadinya kerusakan pada sumber daya alam. Aktivitas diperkenankan antara lain rekreasi terbatas seperti menyusuri bantaran sungai dengan jalan kaki, dengan fasilitas seperti jalan setapak dan jembatan.

\subsection{Perencanaan Lanskap}

Penataan ruang pada bantaran mengikuti pola alami sungai yang memanjang dan menghindari fragmentasi, sehingga muncul ruang-ruang seperti jalan setapak dan area vegetasi. Sirkulasi kendaraan hanya dibatasi sampai pada area parkir kendaraan yang berada pada bagian barat. Sirkulasi manusia dibuat lurus memanjang mengikuti pola alami serta dua arah. Konsep pemilihan tanaman yaitu tanaman yang memiliki sistem perakaran yang kuat untuk dapat menahan air sehingga mencegah terjadinya erosi dan mendukung konservasi air dan tanah.

Pada perencanaan ini terdapat produk yang dihasilkan berupa site plan yaitu gambar final dari konsep pengembangan yang dapat dilihat pada Gambar 6.

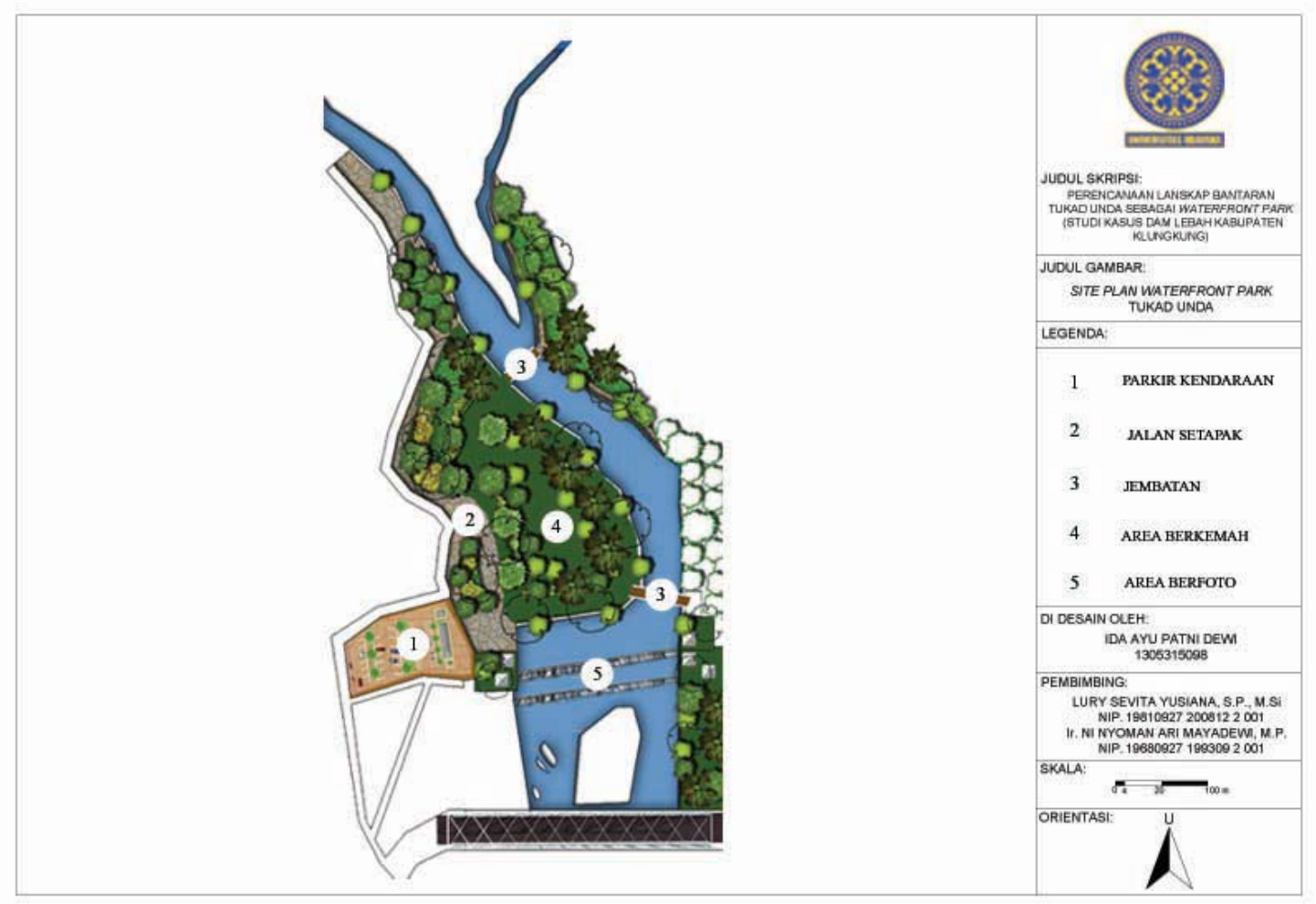

Gambar 6. Site Plan Waterfront Park Tukad Unda 


\section{Simpulan dan Saran}

\subsection{Simpulan}

Perencanaan lanskap Tukad Unda sebagai waterfront park dapat memberikan ruang untuk berbagai aktivitas dan fasilitas. Aktivitas yang dibutuhkan masyarakat seperti bersosialisasi dan berekreasi dengan fasilitas seperti jalan setapak dan jembatan yang menghubungkan antara bantaran bagian timur dan bantaran bagian barat. Pemanfaatan waterfront park memiliki fungsi meningkatkan resapan air, mengurangi erosi tanah, mengurangi pencemaran udara, suplai oksigen dengan penambahan dan penataan vegetasi pada tapak seperti Leucaena leucocephala, Mangifera indica, Cordyline australis, Bambusa sp., Magnolia champaca, Cocos nucifera, Musa paradisiaca, Carica papaya, Muntingia calabura L., Arthocarpus integra, Cananga odorata, Erythrina cristagalli, Eugenia polyantha, Manilkara kauki, Cinnamomun burmanni. Waterfornt park juga dapat meningkatkan nilai estetika lingkungan, menghasilkan lingkungan yang panoramik dan rekreatif pada daerah sekitar Tukad Unda. Waterfront park di kawasan Tukad Unda selain menjadi ruang terbuka hijau kota bagi masyarakat, juga dapat menjadi ruang interaksi sosial dan masyarakat dapat memanfaatkan waterfront park sebagai tempat berekreasi. Dalam perencanaan waterfront park terdapat zona aktivitas dan fasilitas untuk mendukung kegiatan rekreasi yang sesuai dengan kebutuhan tapak.

\subsection{Saran}

Perlu dilakukan penelitian lebih lanjut terkait potensi yang ada pada kawasan Tukad Unda, agar dapat meningkatkan nilai estetika serta menjaga keseimbangan sungai.

\section{Daftar Pustaka}

Balai Wilayah Sungai Bali-Penida. (2017). Laporan Akhir Tukad Unda. Balai Wilayah Sungai Bali-Penida.

BPS Kabupaten Klungkung. (2017). Kabupaten Klungkung Dalam Angka 2016. Badan Pusat Statistik Kabupaten Klungkung.

Gold SM. (1980). Recreation Planning and Design. New York: Mc: Graw-Hill Book Company. Hakim, R., dan Utomo, Hardi. (2002). Komponen Perancangan Arsitektur Lanskap. Penerbit: PT. Bumi Aksara, Jakarta. 